\title{
Differentially expressed plasma protein fractions in workers of dyeing unit at a textile industry and comparable controls
}

\author{
N. Roohi* , A. Shaukat, M. A. Iqbal, T. Mumtaz \\ Physiology Research Laboratory, Department of Zoology, University of the Punjab, Quaid-e-Azam Campus, \\ Lahore-54590, Pakistan.
}

\begin{abstract}
Workers of textile industry are exposed to different hazardous chemicals that cause adverse effects on their health. As variations in plasma proteins are the best indicators of health status of the subjects, hence, we compared plasma protein fractions, resolved by SDS-PAGE of textile dyeing industry workers $(n=30)$ with control subjects $(n=30)$. Proteins were quantified by Total Lab Quant software and analyzed, statistically, by Student t-test. Thirteen protein fractions were detected ranging $250-17 \mathrm{kDa}$. A significant increase in $132 \mathrm{and} 53 \mathrm{kDa}$ fractions, whereas, a significant decrement in 87 and $66 \mathrm{kDa}$ fractions with a highly significant reduction in $112 \mathrm{kDa}$ fraction was observed. However, $250,224,43,23,19$ and $17 \mathrm{kDa}$ protein fractions did not vary considerably. As some proteins circulate only during particular physiological or pathological circumstances and may serve as biomarkers of anomalies, the altered expressions of these biomolecules observed in textile dyeing industry workers may be strong predictors of different ailments.
\end{abstract}

Keywords: Dyeing unit; Electrophoresis; Proteins; SDS-PAGE; Textile industry workers

\section{Introduction}

Textile environments are usually huge sources of countless organic and inorganic compounds like caustic soda, acetic acid, sulphuric acid, hydrochloric acid, fixing agents, softeners, filling agents, polyvinyl acetate (PNA), etc (Dabra et al. 2012).

Dyeing is one of the crucial parts in the textile sector wherein the workers usually have serious health problems like skin and respiratory disorders (Vlandreen et al. 2010). Workers in this environment are always been exposed to various harmful substances from different point and non point sources. Data have shown that majority of the laborers present in industrial environments are exposed to different volatile organic compounds (VOC) evolved from polythene, construction, dyeing, and many other building materials (Barro et al. 2009).

Common determinants of workplace hazards include lack of the use of self-protective equipments, active and passive exposure to cigarette smoke and socio-demographic as well as economic history of workers (Kamal et al. 2012).

Dyeing unit poses various threats to the ecosystem. It generates various toxic substances including colorants in the form of pollutants during various operational stages of textile industry (Verma et al. 2012). These pollutants include formaldehyde, various dyes like azodyes and reactive dyes. These chemicals are hazardous to health and manifest different ailments in the subjects that are being exposed to these substances. Professional exposure to these chemicals is usually in the form of passive and active exposure as different working operational sites work in coordination with each respective part in sequential order. Proteins are involved in all cell functions, normal bodily growth and metabolism, hence, variations in these biomolecules cause abnormal functioning of cells and manifest different ailments. Therefore, the objective of the present preliminary study is to utilize SDS-PAGE (Sodium dodecylsulphate-Polyacrylamide Gel Electrophoresis) to explore potential protein biomarkers in workers occupationally exposed to textile dyeing unit.

\section{Materials and methods}

Blood samples of textile dyeing male workers $(n=30$, age 20-45 years) were collected from a local textile unit. Age and sex matched controls of same socioeconomic status were sampled from the local population with the help of registered technician.

\footnotetext{
*Corresponding author: E-mail: nabilaruhi@gmail.com
} 
The protocol was approved by Ethical Review Committee, University of the Punjab. A proforma was designed to collect the complete information about the medical condition of the exposed workers. All of the subjects, willingly and voluntarily, participated in the study. Complete information related to the study was collected from each participant by a comprehensive questionnaire. Inclusion criteria were 15 years exposure to textile environments and the absence of any co-morbidity like diabetes, hepatitis $\mathrm{C}$, blood pressure, etc.

Blood samples of both workers and controls were collected in pre-coated EDTA vaccutainers and processed for plasma separation. Protein profile was analyzed by SDS-PAGE which resolves protein fractions on the basis of their molecular weights (Laemmli, 1970). Polyacrylamide gels (12\% and 6\%) were prepared, for analyzing low and high molecular weight protein fractions, respectively. Selected samples were thawed in a water bath adjusted at $37^{\circ} \mathrm{C}$. Two $\mu$ l of sample and $998 \mu \mathrm{l}$ of deionized water were dispensed in a falcon tube. Five $\mathrm{ml}$ of Bradford reagent was also added in the solution. Gently mix the whole ingredients and avoid foaming. The solutions were again incubated at $37^{\circ} \mathrm{C}$ for 15 minutes. Absorbances of individual samples were noted at $595 \mathrm{~nm}$ and the protein concentration was determined by standard curve.

Loading dye containing, $0.2 \mathrm{~g}$ of SDS (sodium dodecyl sulphate) $0.154 \mathrm{~g}$ of DTT (dithiothretiol) $20 \mathrm{mg}$ of bromophenol blue dye, $1 \mathrm{ml}$ of glycerol mixed in $0.5 \mathrm{ml}$ of Tris ( $\mathrm{pH}$ 6.8) was prepared. Final volume was made upto 10 $\mathrm{ml}$ by adding deionized water.

As human plasma contains varied amounts of proteins, hence, a stock solution was prepared for each of the samples by adding $2 \mu \mathrm{l}$ of plasma in $18 \mu \mathrm{l}$ of deionized water. Working dilutions were prepared by diluting calculated amount of each stock solution upto $20 \mu \mathrm{l}$ with deionized water. Added $20 \mu \mathrm{l}$ of loading dye to each of the working dilutions and vortexed. Each of the working dilutions contained equal amount of protein which was $100 \mu \mathrm{g} / 40 \mu \mathrm{l}$. Samples were heated at $95^{\circ} \mathrm{C}$ for 15 minutes to denature proteins. In each well of the gel $25 \mu \mathrm{g} / 10 \mu \mathrm{l}$ of protein was loaded. Protein marker and each of the samples were loaded in separate wells. Gels were electrophoresed at a current supply of $30 \mathrm{~mA}$ and $200 \mathrm{~V}$, in a cooling chamber maintained at $4^{\circ} \mathrm{C}$ until the dye reached the lower end of the gel. The gel was then stained with coomassie blue for 1 hour with constant agitation and destained afterwards until the clearance of blue background.

The gels were scanned for quantification of separated protein fractions by Total Lab Quant Software that provided the data of molecular weights and band percentage covered by each of the fractions. The data were analyzed using Student t-test and employed in finding the enhancement/reduction and appearance/disappearance of particular protein fractions for comparison between the controls and the workers.

\section{Results}

Variations in the plasma protein fractions of textile industry workers were remarkable when compared to control subjects. An overall comparison of plasma protein profiles of both control and workers groups indicated the expression of thirteen protein fractions ranging between $250-17 \mathrm{kDa}$ (Table 1). Protein fractions of 132 and $53 \mathrm{kDa}$ showed significant increase, whereas, 112,87 and $66 \mathrm{kDa}$ protein fractions indicated a significant decrease in workers compared to control subjects. However, no significant variations were observed in $250,224,43,23,19$ and $17 \mathrm{kDa}$ protein fractions in both of the comparable groups (Table I, Fig. 1).

\section{Discussion}

Occupational health is the most concerned area in the world because these environments do have a lot of potentially hazardous pollutants which manifest various detrimental health related problems. Textile sector is the most frequently discussed working environment in the world. Workers in these environments possess different ailments that are attributed to the exposure of these chemical substances.

In present investigation, the protein profile of healthy subjects and dyeing unit workers was studied by SDS-PAGE. The protein fractions ranged between $250-17 \mathrm{kDa}$ in controls and the workers group.

Protein fraction of $132 \mathrm{kDa}$ reported as ceruloplasmin, a glycoprotein in human serum, has shown significant elevation in workers compared to control group, in the present study (Mazumder et al. 1997). Ceruloplasmin is an antioxidant due to its acute phase reactant property, whose elevated concentration is observed in infection, inflammation, trauma, etc (Vassiliev et al. 2005). In workers of textile industry, different infections have been observed related to lungs and reproductive system such as respiratory disorders and trauma or cancer of reproductive organs. Increase of ceruloplasmin may indicate the risks of these disorders in workers of dyeing unit.

Protein fraction of $112 \mathrm{kDa}$ has shown highly significant decrease in workers compared to control group. This protein has been recognized as plasminogen and its declined level was reported in a disorder which causes pseudomembranes progression on mucosal surfaces, with subsequent end-organ impairment of the affected tissue (Metha and Shapiro, 2008). Pseudomembranes affect ear, gingiva, respiratory tract, skin 
Table I. Average percent raw volumes exhibited by various protein fractions in controls and workers. Values are Mean \pm SEM.

\begin{tabular}{|c|c|c|c|c|}
\hline \multirow[t]{3}{*}{$\begin{array}{c}\text { Molecular weight of } \\
\text { proteins }\end{array}$} & \multicolumn{2}{|c|}{$\begin{array}{l}\text { Average band percentage of protein } \\
\text { fractions }\end{array}$} & \multirow[t]{3}{*}{$\begin{array}{c}\text { Percentage difference of protein fractions in } \\
\text { workers group }\end{array}$} & \multirow{3}{*}{ p-value } \\
\hline & Control group & $\overline{\text { Workers }}$ & & \\
\hline & & Group & & \\
\hline 250 & $03.50 \pm 0.16$ & $02.90 \pm 0.29$ & $17.14 \downarrow$ & 0.0535 \\
\hline 224 & $03.10 \pm 0.15$ & $02.70 \pm 0.25$ & $12.90 \downarrow$ & 0.1338 \\
\hline 165 & $04.60 \pm 0.13$ & $04.60 \pm 0.35$ & No change & 0.9958 \\
\hline 132 & $03.20 \pm 0.08$ & $03.60 \pm 0.13$ & $12.50^{* *} \uparrow$ & 0.0096 \\
\hline 112 & $04.60 \pm 0.10$ & $03.50 \pm 0.28$ & $23.91^{* * *} \downarrow$ & 0.0003 \\
\hline 87 & $04.10 \pm 0.19$ & $03.30 \pm 0.22$ & $19.51^{*} \downarrow$ & 0.011 \\
\hline 71 & $11.00 \pm 0.35$ & $10.00 \pm 0.38$ & $9.09 \downarrow$ & 0.179 \\
\hline 66 & $36.00 \pm 0.54$ & $34.61 \pm 0.78$ & $5.50^{*} \downarrow$ & 0.043 \\
\hline 53 & $17.00 \pm 0.46$ & $19.00 \pm 0.45$ & $11.76^{* * \uparrow}$ & 0.003 \\
\hline 43 & $12.00 \pm 0.26$ & $11.00 \pm 0.24$ & $8.30 \downarrow$ & 0.2244 \\
\hline 23 & $16.00 \pm 0.48$ & $16.00 \pm 0.40$ & No change & 0.4037 \\
\hline 19 & $04.30 \pm 0.17$ & $04.00 \pm 0.22$ & $6.96 \downarrow$ & 0.3535 \\
\hline 17 & $02.70 \pm 0.11$ & $02.70 \pm 0.14$ & No change & 0.9719 \\
\hline
\end{tabular}

$\downarrow$ Decrease, $\uparrow$ Increase, Significant at $* \mathrm{p}<0.05, * * \mathrm{p}<0.01, * * * \mathrm{p}<0.001$
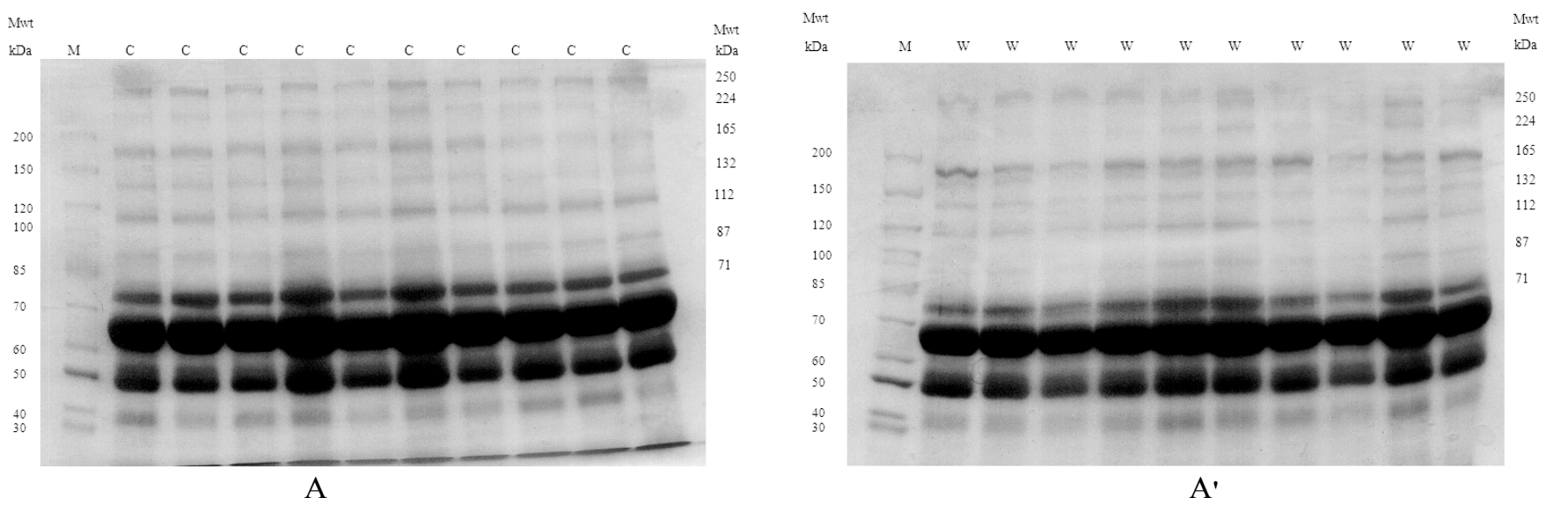

Fig. 1. Photographs showing electrophoretically resolved high molecular weight $\left(A, A^{\prime}\right)$ plasma protein factions in distinct bands in control subjects (C) and workers group (W).

$\mathrm{M}=$ Protein markers with known molecular (Mwt) in kilodaltons (kDa).

and renal collecting system. It has been reported by dermatologists that textile dyes may cause skin reactions (Hatch and Maibach, 1995). Studies have also shown that the highest frequency of chronic respiratory diseases like dyspnea, rhinitis, sinusitis, cough, hoarseness and chronic phlegm was observed in exposed workers than in healthy controls (Zuskin et al. 1997).
Protein fraction of $87 \mathrm{kDa}$ showed significant decrease in workers compared to control group. It is referred to as serotransferrin found in some external secretions and blood. In physiological and pathological conditions, important alterations of plasma serotransferrin concentration are observed (Inoue et al. 1993). Serotransferrin, identified in the bladder tumor donors group was found to be decreased 
as compared to healthy group (Kreunin et al. 2007). Textile industry workers have been exposed to dyes encompassing aromatic amine derivatives for many years. Some of these compounds have the ability to induce tumors, particularly, urinary bladder tumors in humans (IARC, 1982; Hicks et al. 1982). The declined level of serotransferrin observed in workers group of the present investigation can be the risk factor for bladder cancer in textile workers.

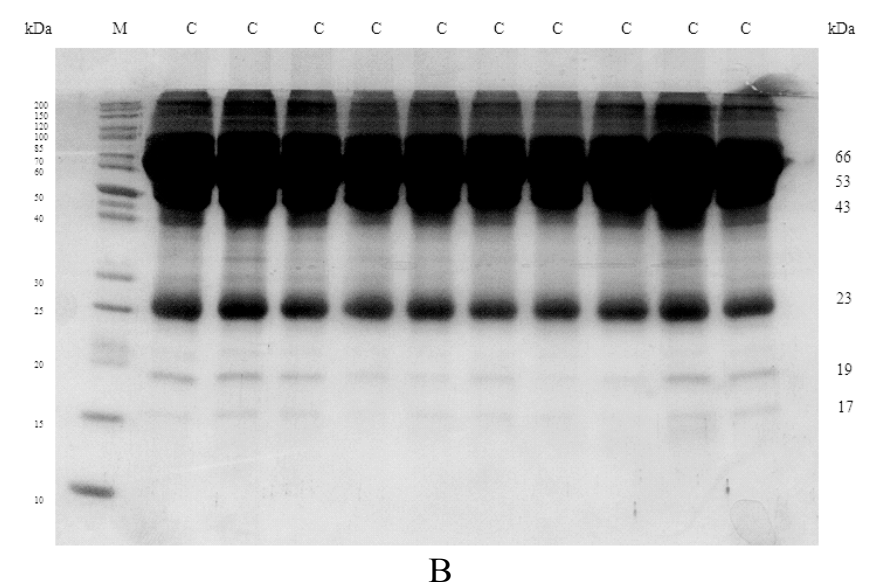

\section{Conclusion}

The up-regulation and down-regulation of different protein fractions is attributed to risk of different diseases. Such as the up-regulation of $132 \mathrm{kDa}$ as observed in our study is a risk factor of lungs and reproductive system impairments. Moreover, the protein fraction of $53 \mathrm{kDa}$ is up-regulated which is marker of allergic asthma. The

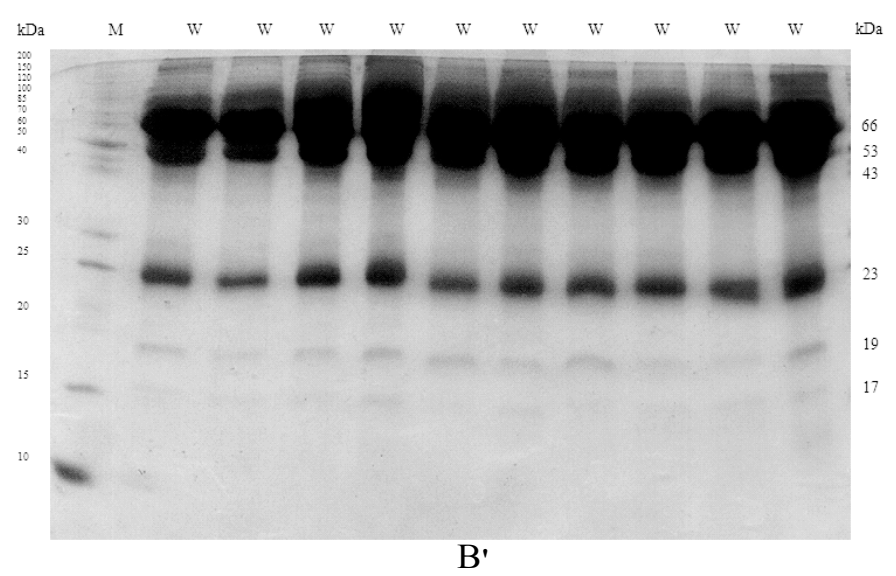

Fig. 2. Photographs showing electrophoretically resolved low molecular weight $\left(B, B^{\prime}\right)$ plasma protein factions in distinct bands in control subjects (C) and workers group (W).

$\mathrm{M}=$ Protein markers with known molecular (Mwt) in kilodaltons (kDa).

In our study, protein fraction of $66 \mathrm{kDa}$ (albumin) was found to be declined in workers group in comparison to control subjects. It is reported that decline in albumin concentration of $2.5 \mathrm{~g} / 1$ predicts coronary heart disease (CHD) and increased mortality in elderly men. Serum albumin quantity less than normal range may occur in various disorders (Weijenberg et al. 1997). Among these ailments are those attributed to malabsorption and malnutrition, in such cases protein is either not properly metabolized in food or is depleted through the gastrointestinal tract (Waldmann, 1972). Moreover, reduced albumin quantity is frequently evident in patients with liver ailments, cancer and sepsis (Ballmer et al. 1993; Pasanisi et al. 2001; Ruot et al. 2000).

Protein fraction of $53 \mathrm{kDa}$ exhibited a significant elevation in workers group as compared to control individuals. Estimate of the molecular mass of the soluble CD14 by SDS-PAGE is considered to be $50-53 \mathrm{kDa}$ (Bazil et al. 1986). In vivo, higher levels of soluble CD14 have been reported in bronchoalveolar lavage (BAL) fluid in pulmonary disorders such as tuberculosis, sarcoidosis, allergic alveolitis and idiopathic pulmonary fibrosis (Heitbrock and Ulevitch, 1993; Pforte et al. 1994; Striz et al. 1995; Hoheisel et al. 1995). Elevated level of soluble CD14 is a marker of allergic asthma, as observed in workers group of the present study. down-regulation of $112 \mathrm{kDa}$ in present study is associated with skin disorders which are prominent in the workers of dyeing unit. The down-regulation of $87 \mathrm{kDa}$ is a risk factor for bladder cancer, while the down-regulation of $66 \mathrm{kDa}$ is a marker of cardiac and liver ailments.

Hence, workers in dyeing unit are at a risk of cardiac, liver, skin and respiratory disorders. Preventive measures such as the use of gloves, masks, a proper covered uniform, and large sized glasses must be strictly observed in workers of dyeing unit. Work hours should be reduced to minimize the duration of exposure. Further, workers should be screened regularly for manifestation of various disorders so that an early prediction and effective treatment strategies may be opted to improve the quality of their lives.

\section{Acknowledgements}

Our special thanks to Muhammad Iqbal, Muhammad Zahid and volunteers of the study for their successful participation in the process of blood sampling.

\section{Declaration of conflicting interest}

The authors declare no conflict of interest with respect to authorship and publication of this article. 


\section{Funding}

This research received no specific grant from any funding agency in the public, commercial, or not-for-profit sectors. The research work was completed utilizing the resources available at University of the Punjab, Quaid-e-Azam Campus Lahore Pakistan.

\section{References}

Ballmer PE, Walshe D, Mcnurlan MA, Watson H, Brunt PW and Garlick PJ (1993), Albumin synthesis rates in cirrhosis: correlation with Child - Turcotte classification, Hepatology, 18: 292-297.

Barro R., Regueiro J, Lompart M and Jares CG (2009), Analysis of industrial contaminants in indoor air. Part 1. Volatile organic compounds, carbonyl compounds, polycyclic aromatic hydrocarbons and polychlorinated biphenyls, J Chromatogr A. 1216: 540-566.

Bazil V, Horejsi V, Baudys M, Krsitofova H., Strominger JL, Kostka W and Hilgest I (1986), Biochemical characterization of a soluble form of $53 \mathrm{kDa}$ monocyte surface antigen, Eur $J$ immunol. 16: 1583-1589.

Dabra RM, Gonzalezdan JR, Casal A, Agueda A, Capri E, Fait G, Schuhmacher M, Nadal M, Rovira J, Grundmann V, Bercelo D, Guillen D E (2012), Additives in the Textile Industry. (Springer Heidelberg Dordrecht London New York) 2012, pp83-107.

Hatch KL and Maibach HI (1995), Textile dye dermatitis, $J$ Am Acad Dermatol. 32: 631-639.

Heitbrock HW and Ulevitch RJ (1993), CD14: cell surface receptor and differentiation marker, Immunol Today, 14: $121-125$.

Hicks RM, Wright R and Field JSW (1982), The induction of rat bladder cancer by 2-naphhylamine, Br J Cancer, 46: 646-661.

Hoheisel G, Zheng L, Teschler H, Striz I and Costabel U (1995), Increased soluble CD14 levels in BAL Fluid in pulmonary tuberculosis, Chest, 108: 1614-1616.

Inoue T, Cavanaugh PG, Steck PA, Brunner N and Nicolson GL (1993), Differences in transferrin response and numbers of transferrin receptors in rat and human mammary carcinoma lines of different metastatic potentials, J Cell Physiol. 156: 212-217.
International Agency for Research on Cancer (IARC), IARC (1982), Monographs on the evaluation of the carcinogenic risk of chemicals to humans. Some industrial chemicals and dyestuffs, WHO IARC, Lyon France. 94-148.

Kamal A, Malik RN, Fatima N and Rashid A (2012), Chemical exposure in occupational settings and related health risks: A neglected area of research in Pakistan, Environ Toxicol Pharmacol. 34: 46-58.

Kreunin P, Zhao J, Rosser C, Urquidi V, Lubman DM and Goodison S (2007), Bladder cancer associated glycoprotein signatures revealed by urinary proteomic profiling, J Proteome Res. 6: 2631-2639.

Laemmli UK (1970), Cleavage of structural proteins during the assembly of the head of bacteriophage T4, Nature, 227: 680-685.

Mazumder B, Mukhopadhyay CK, Prok A, Cathcart MK and Fox PL (1997), Induction of ceruloplasmin synthesis by IFN-gamma in human monocytic cells, $J$ Immunol. 159: 1938-1944.

Mehta R and Shapiro A.D (2008), Plasminogen deficiency, Haemophilia, 14: 1261-1268.

Pasanisi F, Orban A, Scalfi L et al. (2001), Predictors of survival in terminal-cancer patients with irreversible bowel obstruction receiving home parenteral nutrition, Nutrition, 17: 581-584.

Pforte A, Schiessler A, Gais P et al. (1994), Expression of CD14 correlates with lung function impairment in pulmonary sarcoidosis, Chest, 105: 349-354.

Ruot B, Breuille D, Rambourdin F, Bayle G, Capitan P and Obled C (2000), Synthesis rate of plasma albumin is a good indicator of liver albumin synthesis in sepsis, $\mathrm{Am}$ J Physiol: Endocrinol Metabol. 279: E244-251.

Striz I, Zheng L, Wang YM, Pokorna H, Bauer PC and Costabel U (1995), Soluble CD14 is increased in bronchoalveolar lavage of active sarcoidosis and correlates with alveolar macrophage membrane-bound CD14, Am J Respir Crit Care Med. 151: 544-547.

Vassiliev V, Harris ZL and Zatta P (2005), Ceruloplasmin in neurodegenerative diseases, Brain Res Brain Res Rev. 49: $633-640$. 
Verma AK, Dash RR and Bhunia P (2011), A review on chemical co agulation/ flocculation technologies for removel color from textile waste water, $J$ environ manage. 93: 154-168

Vlandreen J, Moore LE, Smith MT, Lan Q, Zhang L, Skibola CF et al. (2010), Application of OMICS technologies in occupational and environmental health research; current status and projections, Occup Environ Med. 67: 13643.

Waldmann TA (1972), Protein-losing enteropathy and kinetic studies of plasma protein metabolism, Semin Nucl Med. 2: 251-263.
Weijenberg MP and Feskens EJ, Souverijn JH, Kromhout D (1997), Serum albumin, coronary heart disease risk, and mortality in an elderly cohort, Epidemiol. 8: 87-92.

Zuskin E, Mustajbegovic J, Schachter EN and Doko J (1997), Respiratory function of textile workers employed in dyeing cotton and wool fibers, Am J Indus med. 31: 344-352.

Received: 18 November 2013; Revised: 6 April 2014; Accepted: 2 July 2014. 